\title{
Analysis of trace elements concentrations in atmospheric deposition in Haerbin city, Northeast China
}

\author{
Li Na ${ }^{1, *}$, Han Weizheng ${ }^{2}$ \\ 1. Key Laboratory of Songliao Aquatic Environment, Ministry of Education, Jilin Jianzhu university, \\ Changchun 130118, PR china;
}

2.Changchun Institute of Urban Planning \& Designing, Changchun. 130031, PR. China

Keywords: Atmospheric deposition; Trace element; Principal component analysis (PCA); Haerbin City.

Abstract. With the development of industrialization and civilization, the atmospheric depositions in Haerbin city degraded in recent years. 46 deposition samples were collected to analyze their concentrations of ten elements including Mn, Zn, Pb, Cu, Cr, Ni, As, Co, Cd, Hg in 2008 2009. The samples were analyzed for heavy metal concentration by atomic fluorescence spectrometry and Inductively Coupled Plasma-Atomic Spectrometry (ICP-AES). The elements, except Mn and Co, are associated different anthropogenic sources by comparing concentrations to China soil. The deposition flux was calculated. Sources analysis was made by the method of pearsons, principal component analysis (PCA). Three sources associated by the analysis are: (1) coal combustion $\mathrm{Cr}, \mathrm{Mn}, \mathrm{Zn}, \mathrm{Hg}, \mathrm{Cd}$ and As; (2) road traffic emissions associated with $\mathrm{Pb}$; (3) metal smelting contributing $\mathrm{Cu}$. What's more, $\mathrm{Co}$ is mainly from crust weathering. The paper can support the scientific research in atmospheric deposition in Haerbin city.

\section{Introduction}

Rapid industrialization, urbanization, economic growth and associated increase in energy demands have led to a great deterioration of air quality and provoked some serious environmental concerns. Little environmental control has resulted certain problems in air pollution ${ }^{[1,2,3]}$. Atmospheric emissions of gaseous and particulate pollutants have caused profound environmental and health implications in recent years. Because metals do not degrade naturally, high concentration in atmospheric deposition can result accumulation in soil at levels that are toxic to organisms in surrounding environment. It is well recognized that many heavy metals have chronic effects on humans, particularly to young children ${ }^{[4]}$. Some trace metals at small amounts are harmless and some are toxic at high concentration. However, some are toxic to human health even at extremely low concentrations. What's more, excessive inputs of heavy metals into the surface environment by atmospheric deposition can bring a long term burden on biogeochemical cycling in the ecosystem. It is therefore urgent to understand the concentrations and sources of trace elements especially heavy metals in atmospheric deposition.

In recent decades, there has been a growing concern for atmospheric deposition in America ${ }^{[5,6]}$, Europe $^{[7,8]}$, even in some regions in Asia ${ }^{[9,10]}$. The moss technique developed in 1970 has been widely used in many parts of the world to estimate trace elements in atmospheric depositions ${ }^{[11,12]}$. But the moss technique is scarcely used in Asia. To implement this international reliable and cheap methodology in Asian countries, it is necessary to find proper moss types typical for the Asian environment and suitable for the biomonitoring purposes. It is far to know there is no typical research based on moss biomonitoring in China, especially in northern region due to its long-term-winter. Besides moss monitoring method, direct collection of atmospheric deposition using various sampling devices offers a more practical approach to monitor atmospheric heavy metal deposition.

Furthermore, different trace metals are contributed by different sources, including soil, coal incineration, vehicle emissions and various industrial processes. However, there are obvious spatial variability in the sources of trace elements among different study regions due to its meteorological conditions, economic 
activities, and stages of industrialization and urbanization. Same metals may mainly derive from alternative sources. In order to assess the impact of trace elements in atmospheric deposition on environment and human health, it is necessary to come out a geography survey to investigate the concentration of trace elements in atmospheric deposition. Haerbin is the capital of Heilongiiang province, in northern China, which is experiencing much more rapid economic, industrial development than other northern cities. The winter is very long and amounts of coal are consumed to support district heating, which provokes serious atmospheric pollutants. However, to our knowledge, no study on this topic has been carried out in this area.

The objective of this study are: (1) to determine concentrations of 10 trace elements $(\mathrm{Co}, \mathrm{Cr}, \mathrm{Cu}, \mathrm{Mn}$, $\mathrm{Ni}, \mathrm{Pb}, \mathrm{Zn}, \mathrm{Hg}, \mathrm{Cd}$ and $\mathrm{As}$ ) in atmospheric deposition in Haerbin city of Heilongjiang province, northern China; (2) to compare the concentrations of trace elements to other country in China and realize the atmospheric pollution levels in Haerbin city; (3) to divide the sources of each elements from natural and anthropogenic by using multivariate analysis; (4) to identify the degree of anthropogenic influence on trace elements in atmospheric deposition. This study can provide an overall picture on the spatial difference of trace elements in atmospheric deposition and scientific data to environmental control.

\section{Materials and methodologies}

\section{Study area}

Haerbin city, the capital of Heilongjiang province, is situated in the south of Heilongjiang province in China whose area is $5.3 \times 10^{4} \mathrm{~km}^{2}$ with $317.97 \mathrm{~km}^{2}$ in urban. There are five regions in urban, namely Songbei, Daoli, Daowai, Nan'gang and Xiangfang. The city is located in temperate continental monsoon climate zone, with annual temperature being $-41.4 \sim 36.2^{\circ} \mathrm{C}$, while the average annual rainfall is $567 \mathrm{~mm}$. In this area, the climate characteristics are short summer and long winter lasted above 5 months with 190 freezing day. Since the 1950s, Haerbin has been gradually developing into an important industrial city in China, in which the major industries are heavy metal industry, textile industry and chemical industry.

Rapid economic growth and heating in winter has resulted in an increase in energy consumption. Almost all of the energy that sustains the industries in this area comes from coal-fired power plants. The number of raw coal consumption in these plants exceeds 112 million tones.

\section{Sampling and chemical analysis}

Forty-six samples of atmospheric depositions were collected successively from April 19th 2008 to April 19 th 2009 using a porcelain cylinder ( $20 \mathrm{cminner}$ diameter, $40 \mathrm{~cm}$ in height) covered with a polyethylene web which prevents large size materials.

Porcelain cylinders were soaked with $10 \% \mathrm{HCl}$ and washed with deionized water. Sampling sites were free from the influence of nearby heavy metal sources and no obstacles including high buildings and trees in the surrounding areas of $25 \mathrm{~m}$ multiply $25 \mathrm{~m}$. Sampling outlet was $1.0 \mathrm{~m}$ higher than platform. Leaves and insects were sorted out from sampling using tweezers. The cylinder walls were washed several times and all of precipitates and suspensions were transferred into polyethylene buckets. The total dusts were taken into porcelain crucibles whose volume is $100 \mathrm{ml}$, which evaporated on electric hot plates and were dried in an oven at $65^{\circ} \mathrm{C}$ for 24 hours. The concentrations of trace elements in atmospheric depositions were analyzed including $\mathrm{Mn}, \mathrm{Zn}, \mathrm{Pb}, \mathrm{Cu}, \mathrm{Cr}, \mathrm{Ni}, \mathrm{As}, \mathrm{Co}, \mathrm{Cd}$ and $\mathrm{Hg}$. The concentrations of As and $\mathrm{Hg}$ were measured using atomic fluorescence spectrophotometer (AFS-230E), and others were determined using inductive coupling plasma emission spectroscopy (ICP-AES). The accuracy of the analytical procedures employed for the analysis of the trace elements in atmospheric depositions was checked using the GSS certified reference material.

\section{Descriptive analysis and correlation analysis}

Descriptive data analysis, including mean values, standard deviation (SD), minimum and maximum concentrations, skewness, and variation coefficient, etc., was performed on the concentrations of the trace 
elements. VC was generally used to reflect the degree of discrete distribution of different trace elements concentrations. Skewness calculation characterizes the degree of asymmetry of a distribution around the mean values. Correlation coefficients were also calculated to analyze the relationships among different elements in order to identify similar sources of element.

PCA and CA were applied in order to point out the correlation structure among particulate concentrations and heavy metal content and to highlight source profile characterization. PCA was applied to the data matrix to evaluate the analytical results and to identify the possible pollution sources of metals. The source identification was carried out by PCA and CA. Correlation analysis and PCA were applied to the data matrix to evaluate the analytical results and to identify the possible pollution sources of metals. Factor analysis showed that these areas were mainly contaminated by three sources, namely lithology, traffic, and industry.

\section{Results and discussion}

\section{Trace element concentration}

Table 1 shows the statistical summary for the heavy metal concentrations of atmospheric deposition in study area as well as the background values of Chinese soil, which are considered as the reference values. The mean concentration of $\mathrm{Mn}$ is higher. The mean concentrations of other metals are in order of $\mathrm{Zn}>\mathrm{Pb}>$ $\mathrm{Cu}>\mathrm{Cr}>\mathrm{Ni}>\mathrm{As}>\mathrm{Co}>\mathrm{Cd}>\mathrm{Hg}$. The highest is $\mathrm{Zn}$ with mean concentration of $370.77 \mathrm{mg} \bullet \mathrm{kg}^{-1}$. The lowest is $\mathrm{Hg}$ with an average of $0.25 \mathrm{mg} \bullet \mathrm{kg}^{-1}$.

Table 1 Heavy metal concentrations of atmospheric deposition in Haerbin city

\begin{tabular}{ccccccccc}
\hline Element & Minimum & Maximum & Mean & Median & SD & VC & Skewness & Reference values $^{1}$ \\
\hline $\mathrm{Co}\left(\mathrm{mg} \cdot \mathrm{kg}^{-1}\right)$ & 8.50 & 17.50 & 11.85 & 12.05 & 1.67 & 0.14 & 0.68 & 12.70 \\
$\mathrm{Cr}\left(\mathrm{mg} \cdot \mathrm{kg}^{-1}\right)$ & 51.70 & 756.00 & 87.13 & 66.65 & 102.93 & 1.18 & 6.37 & 61.00 \\
$\mathrm{Cu}\left(\mathrm{mg} \cdot \mathrm{kg}^{-1}\right)$ & 29.10 & 1371.00 & $\mathbf{1 0 4 . 9 0}$ & 74.05 & 192.78 & 1.84 & 6.57 & 22.60 \\
$\mathrm{Mn}\left(\mathrm{mg} \cdot \mathrm{kg}^{-1}\right)$ & 365.60 & 940.40 & $\mathbf{5 6 6 . 1 4}$ & 560.65 & 92.12 & 0.16 & 1.53 & 583.00 \\
$\mathrm{Ni}\left(\mathrm{mg} \cdot \mathrm{kg}^{-1}\right)$ & 17.30 & 200.00 & 34.58 & 27.00 & 28.91 & 0.84 & 4.77 & 26.90 \\
$\mathrm{~Pb}\left(\mathrm{mg} \cdot \mathrm{kg}^{-1}\right)$ & 46.60 & 512.00 & $\mathbf{1 1 7 . 1 5}$ & 98.55 & 75.98 & 0.65 & 3.78 & 26.00 \\
$\mathrm{Zn}\left(\mathrm{mg} \cdot \mathrm{kg}^{-1}\right)$ & 156.10 & 980.40 & $\mathbf{3 7 0 . 7 7}$ & 351.25 & 134.85 & 0.36 & 2.14 & 74.20 \\
$\mathrm{Hg}\left(\mathrm{mg} \cdot \mathrm{kg}^{-1}\right)$ & 0.09 & 0.62 & 0.25 & 0.22 & 0.12 & 0.48 & 1.02 & 0.06 \\
$\mathrm{Cd}\left(\mathrm{mg} \cdot \mathrm{kg}^{-1}\right)$ & 0.81 & 5.46 & 1.46 & 1.30 & 0.76 & 0.52 & 3.62 & 0.10 \\
$\mathrm{As}\left(\mathrm{mg} \cdot \mathrm{kg}^{-1}\right)$ & 1.00 & 46.00 & 23.50 & 23.50 & 13.42 & 0.57 & 0.00 & 11.20 \\
\hline
\end{tabular}

1,2: The background concentration of heavy metal through the nation from Background value of soil trace elements in China.

Each element has a wide range concentration except Mn and Co. Besides this, the mean concentrations of Mn and Co are $566.14 \mathrm{mg}^{\bullet} \mathrm{kg}^{-1}$ and $11.85 \mathrm{mg} \mathrm{kg}^{-1}$, which are very close to the reference values, suggesting they might have a natural source. The ratio of mean concentration and reference values in other elements are in order of $\mathrm{Cd}>\mathrm{Zn}>\mathrm{Cu}>\mathrm{Pb}>\mathrm{Hg}>\mathrm{As}>\mathrm{Cr}>\mathrm{Ni}$. The average $\mathrm{Cd}$ concentration is 14.60 times higher than reference value; the lowest concentration $\mathrm{Ni}$ is still 1.22 times higher than reference value. Thus, the higher concentrations of these trace elements in atmospheric deposition than the reference values suggest that they might be mainly contributed by anthropogenic sources.

Skewness values indicate that As approach a normal distribution. On the contrary, the other elements except Co are positively skewed toward the lower concentrations, as also confirmed by the fact that the median concentrations of these elements are much lower than their mean concentrations. The trace elements can be divided into two groups according to their VCs. The values of VCs above 0.2 of trace elements are expected that the elements dominated by certain anthropogenic sources. Thus, the results of skewness and VC calculations suggest that concentrations of trace elements in atmospheric depositions at different sites in the study area exhibit great spatial variability, which are affected by both resuspension of soil particles and anthropogenic sources. 


\section{Atmos pheric deposition of metals}

We summarizes the basic statistics of annual atmospheric deposition of trace metals in this study. The atmospheric deposition varied greatly in Haerbin city, while the highest is $\mathrm{Zn}$ with $177.24 \mathrm{mg} \cdot \mathrm{m}^{-2} \cdot \mathrm{a}^{-1}$ and the lowest is $\mathrm{Hg}$ with $0.01 \mathrm{mg}^{\bullet} \mathrm{m}^{-2} \cdot \mathrm{a}^{-1}$. At the same time, the high SD indicates pronounced distribution diversity except $\mathrm{Hg}$ and $\mathrm{Cd} . \mathrm{Zn}$ is the highest while $\mathrm{Hg}$ is opposite comparing atmospheric depositions among different cities. As the increasing number of vehicles in urban, tires abrasion may course $\mathrm{Zn}$ enrichment. Besides, coal combustion in winter can also increase $\mathrm{Zn}$ concentration. Due to its highly volatile characteristics, $\mathrm{Hg}$ concentration in atmospheric deposition is the lowest as well as it is liquid form at normal temperature.

The results show that $\mathrm{Cr}, \mathrm{Pb}, \mathrm{Zn}, \mathrm{As}, \mathrm{Hg}$ and $\mathrm{Cd}$ atmospheric depositions in Haerbin city are higher than ones in Changchun and Daqing. High number of coal combustion caused large heating area and long heating duration may bring high concentration of $\mathrm{Cr}$, As, $\mathrm{Hg}$ atmospheric deposition which are from burning coal in Haerbin city. Besides coal combustion, 20 45mg $\mathrm{Hg}$ exists in each fluorescent lamp using during Ice and Snow Festival period, which may lead to high $\mathrm{Hg}$ concentration in atmospheric deposition. In addition, $\mathrm{Pb}$, $\mathrm{Cd}$ high concentrations in atmospheric deposition are also in connection with more and more vehicle number. What's more, $\mathrm{Cr}, \mathrm{Pb}, \mathrm{Zn}$, As, $\mathrm{Hg}$ and $\mathrm{Cd}$ atmospheric depositions in Haerbin city are less than ones in Beijing city. The reason caused this phenomenon is the larger population in Beijing where anthropogenic activities are much more frequent.

Therefore, concentrations of trace elements in atmospheric deposition varied by the reason of industrialization and urbanization development. The distinct differences in the annual atmospheric deposition of trace metals between the study area and the various regions indicates that aerialemissions of $\mathrm{Cr}, \mathrm{Pb}, \mathrm{Zn}, \mathrm{As}$, $\mathrm{Hg}$ and $\mathrm{Cd}$ in Haerbin city are serious, provoking concerns over the potential impact of excessive atmospheric deposition of heavy metal on ecosystem and public health in the city.

\section{Principal component analysis}

PCA was chosen to assist in the identification of the sources of the trace elements. According to the KMO (Kaiser-Meyer-Olkin, 0.865) and Bartlett's criterion ( $\mathrm{p}<0.001)$, the first three components with eigenvalues larger than 1.0 have dominant influences through the Z-standardization and component analysis. The three components contribute $71.95 \%$ of the total variance in the samples. The initial eigenvalue of the first factor is the largest: 4.906 , accounting for $68.18 \%$ of the total variance, which indicates the existence of one dominant emission source or a group of emission sources of some elements. By varimax rotation, the final values of the eigenvectors were obtained.

The first factor is mainly characterized by $\mathrm{Cr}, \mathrm{Mn}, \mathrm{Zn}, \mathrm{Hg}, \mathrm{Cd}$ and As (loading range 0.671 0.921). This result confirms the strong positive relationships among them. The factor might be associated by anthropogenic sources represented by coal combustion which coincides with the factor of numerous coal burning in winter in Haerbin city.

The second factor is characterized by high loading for $\mathrm{Pb}(0.936)$. The factor might be associated by traffic emissions. Road traffic emissions contain not only vehicle exhaust but also tire and brake wear. With rapid civilization and industrialization, the number of automobiles is 6 times more in 2010 than twenty years ago in the city of Ha'erbin. The figure is predicted to exceed 100,000,000 in 3 years.

The factor has the lowest total contribution. It is characterized by greatly high loading for $\mathrm{Cu}$. This factor is clearly associated with the anthropogenic important source represented by metal smelting. Generally, the most important source of $\mathrm{Cu}$ in atmospheric deposition is metal smelting.

What's more, the element of Co has the low loading in factors not only in original and rotated values. It is presumed that $\mathrm{Co}$ is associated with natural source which is corresponded to its concentration approaching reference values. 


\section{Conclusions}

The study on the trace metals in atmospheric deposition from Haerbin city in China reveals a distinct accumulation of $\mathrm{Zn}, \mathrm{Pb}, \mathrm{Cu}, \mathrm{Cr}, \mathrm{Ni}, \mathrm{As}, \mathrm{Co}, \mathrm{Cd}$ and $\mathrm{Hg}$ compared to the reference values. The current results show that mean atmospheric deposition of $\mathrm{Cd}, \mathrm{Zn}, \mathrm{Cu}, \mathrm{Pb}, \mathrm{Hg}, \mathrm{As}, \mathrm{Cr}$ and $\mathrm{Ni}$ are higher than reference values except $\mathrm{Mn}$ and $\mathrm{Co}$. The results show that mean atmospheric depositions of $\mathrm{Cr}, \mathrm{Pb}, \mathrm{Zn}, \mathrm{As}, \mathrm{Hg}$ and $\mathrm{Cd}$ are significant higher than the results reported in Changchun, while the opposite phenomenon is analyzed in Beijing due to its population, heating area, et al.

The trace elements in atmospheric deposition in the study area exhibit great spatial variability in pollution levels and origins. Three main sources of trace metals are identified by correlation analysis, principal component analysis, cluster analysis. $\mathrm{Mn}$ and $\mathrm{Co}$ are attributed to a main origin in resuspension of soil particles. $\mathrm{Cr}, \mathrm{Zn}, \mathrm{Hg}, \mathrm{Cd}$ and As originate mainly from coal combustion. $\mathrm{Pb}$ is a characteristic metal from traffic emissions while $\mathrm{Cu}$ is associated with metal smelting.

\section{Acknowledgements}

The work described in this paper was funded by the Geological Survey of China by grant No. 1212010511217-03. We would like to thank from Heilongjiang Institute of Geological Survey for their technical assistance on the analysis.

\section{References}

[1]BENIN, A. L., SARGENT, J. D., DALTON, M. \& RODA, S. 1999. High concentrations of heavy metals in neighborhoods near ore smelters in northern Mexico. Environmental Health Perspectives, 107, 279-284.

[2] LI, X. D., POON, C. S. \& LIU, P. S. 2001. Heavy metal contamination of urban soils and street dusts in Hong Kong. Applied Geochemistry, 16, 1361-1368.

[3] WANG, Q. R., CUI, Y. S., LIU, X. M., DONG, Y. T. \& CHRISTIE, P. 2003. Soil contamination and plant uptake of heavy metals at polluted sites in China. Journal of Environmental Science and Health Part a-Toxic/Hazardous Substances \& Environmental Engineering, 38, 823-838.

[4] TONG, S. T. Y. \& LAM, K. C. 2000. Home sweet home? A case study of household dust contamination in Hong Kong. Science of the Total Environment, 256, 115-123.

[5] FENG, X. H., MELANDER, A. P. \& KLAUE, B. 2000. Contribution of municipal waste incineration to trace metal deposition on the vicinity. Water Air and Soil Pollution, 119, 295-316.

[6] TURER, D., MAYNARD, J. B. \& SANSALONE, J. J. 2001. Heavy metal contamination in soils of urban highways: Comparison between runoff and soil concentrations at Cincinnati, Ohio. Water Air and Soil Pollution, 132, 293-314.

[7] OZCAN, H. K., DEMIR, G., NEMLIOGLU, S., SEZGIN, N. \& BAYAT, C. 2007. Heavy metal concentrations of atmospheric ambient deposition dust in Istanbul-Bosphorus Bridge tollhouses. Journal of Residuals Science \& Technology, 4, 55-59.

[8] SYLA, A. \& MAKOLLI, S. 2009. Monitoring of Particles Pm10 and Pm2.5 in the Mitrovica Urban Atmosphere - Kosova. Sgem 2009: 9th International Multidisciplinary Scientific Geoconference, Vol Ii, Conference Proceeding, 351-356

[9] HAN, Y. J., HOLSEN, T. M., HOPKE, P. K., CHEONG, J. P., KIM, H. \& YI, S. M. 2004. Identification of source locations for atmospheric dry deposition of heavy metals during yellow-sand events in Seoul, Korea in 1998 using hybrid receptor models. Atmospheric Environment, 38, 5353-5361. 
[10] HUANG, S. S., TU, J., LIU, H. Y., HUA, M., LIAO, Q. L., FENG, J. S., WENG, Z. H. \& HUANG, G. M. 2009. Multivariate analysis of trace element concentrations in atmospheric deposition in the Yangtze River Delta, East China. Atmospheric Environment, 43, 5781-5790.

[11] REIMANN, C., NISKAVAARA, H., KASHULINA, G., FILZMOSER, P., BOYD, R., VOLDEN, T., TOMILINA, O. \& BOGATYREV, I. 2001. Critical remarks on the use of terrestrial moss (Hylocomium splendens and Pleurozium schreberi) for monitoring of airborne pollution. Environmental Pollution, 113, 41-57.

[12] ZECHMEISTER, H. G., DULLINGER, S., HOHENWALLNER, D., RISS, A., HANUS-ILLNAR, A. \& SCHARF, S. 2006. Pilot study on road traffic emissions (PAHs, heavy metals) measured by using mosses in a tunnel experiment in Vienna, Austria. Environmental Science and Pollution Research, 13, 398-405. 